\title{
TECNOLOGIA DE CÉLULAS A COMBUSTÍVEL
}

\section{Hartmut Wendt e Michael Götz}

Institut für Chemische Technologie - Technische Universität Darmstadt - Petersenstraße 20 - 64287 Darmstadt - Alemanha Marcelo Linardi

Instituto de Pesquisas Energéticas e Nucleares IPEN/CNEN-SP - Cidade Universitária - Rua R, 400 - $05422-970$ - São Paulo - SP

Recebido em 26/2/99; aceito em 29/7/99

\begin{abstract}
FUEL CELL TECHNOLOGY. The fuel cell principle was discovered by Sir Grove 150 years ago. However material problems prohibited its commercialization for a long time. A change has been occurring during the last 30 years, so two types of fuel cell technologies can be distinguished: low and high temperature operation cells. Nowadays, only phosphoric acid cells are commercially offered as $200 \mathrm{~kW}_{\text {el }}$ power plants. Membrane cells are more suitable for automobile electrotraction with a very low (or no) environmental impact. The fuel continues, however, to play a very particular role, since hydrogen is not easy to store and to transport. The more promising target is the utilization of liquid methanol. The Brazilian scenario concerning this kind of technology is discussed.
\end{abstract}

Keywords: fuel cells; electrochemistry; electrocatalysis.

\section{INTRODUÇÃO}

Um novo conceito tecnológico de geração de energia surgiu nos últimos anos. As palavras "Células a Combustível" (no Brasil também chamadas de Células de Energia), começam a ser pronunciadas com uma maior freqüência, embora esta tecnologia ainda não esteja bem estabelecida e tampouco já tenha um mercado garantido. Para o leigo, estas células estão relacionadas com eletroquímica e servem para produzir eletricidade de uma maneira mais ecológica e eficiente, praticamente sem emissão de qualquer substância tóxica. Porém, o conceito de células a combustível é bem mais abrangente. Este trabalho representa uma revisão atualizada do artigo "Brennstoffzellentechnik", de H. Wendt e M. Götz, publicado na revista Chemie in unserer Zeit 31(1997) 301-309, e visa, não só introduzir e esclarecer os interessados neste assunto, como também comentar o estado da arte desta tecnologia e sua importância no cenário de energias alternativas. Outro objetivo não menos importante é apresentar um breve panorama desta tecnologia no Brasil.

\section{PRINCÍPIO DE FUNCIONAMENTO E TIPOS DE CÉLULAS A COMBUSTÍVEL}

Como é mostrado no esquema simplificado da Figura 1, células a combustível são, em princípio, baterias de funcionamento contínuo, que produzem corrente contínua pela combustão eletroquímica a frio de um combustível gasoso, geralmente hidrogênio ${ }^{1}$. Assim, hidrogênio é oxidado a prótons num eletrodo de difusão gasosa, liberando elétrons, segundo a reação:

$\mathrm{H}_{2} \rightarrow 2 \mathrm{H}^{+}+2 \mathrm{e}^{-}$

No eletrodo oposto, também de difusão gasosa, considerando-se as células a membrana trocadora de prótons (meio ácido), tem-se a reação:

$2 \mathrm{H}^{+}+2 \mathrm{e}^{-}+1 / 2 \mathrm{O}_{2} \rightarrow \mathrm{H}_{2} \mathrm{O}$

wendt@hrz1.hrz.tu-darmstadt.de

mlinardi@net.ipen.br
A reação global, que é acompanhada de liberação de calor, pode ser escrita da seguinte forma:

$$
\mathrm{H}_{2}+1 / 2 \mathrm{O}_{2} \rightarrow \mathrm{H}_{2} \mathrm{O}
$$

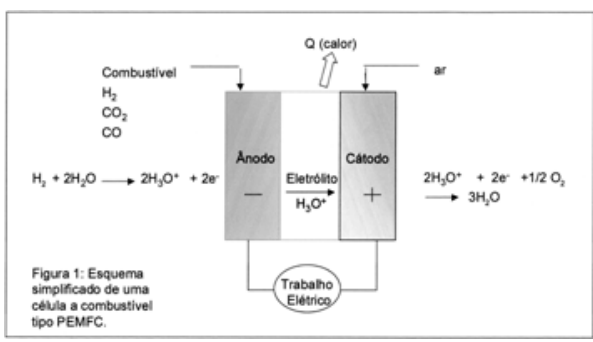

Figura 1

Eletrodos de difusão gasosa são condutores eletrônicos permeáveis aos gases reagentes e são separados um do outro por um eletrólito (condutor iônico), de um modo que os gases não se misturem. O eletrólito pode ser um líquido, um polímero condutor de cátions, saturado com um líquido, ou um sólido (óxido de zircônio). Obtêm-se potenciais de trabalho de célula para o sistema hidrogênio / oxigênio entre 0,5 e $0,7 \mathrm{~V}$. Potenciais de circuito aberto ficam entre 1,1 e 1,2 V. Devido à sua alta reatividade, hidrogênio é, hoje em dia, a escolha mais apropriada para o combustível. Geralmente, classificam-se os vários tipos de células a combustível pelo tipo de eletrólito utilizado e pela temperatura de operação.

Na Tabela 1 estão representados os diferentes tipos de células a combustível, bem como suas características principais. Atualmente, as células do tipo alcalina AFC (Alkaline Fuel Cell) têm um papel importante somente em viagens espaciais, não apresentando aplicação terrestre, devido ao fato de utilizarem somente hidrogênio e oxigênio ultra puros. Além disso, funcionam a uma baixa temperatura de operação e necessitam de um processo relativamente complicado para a remoção da água do eletrólito. Entretanto, este tipo de células foi o precursor das células mais modernas. 
Tabela 1. Tipos de Células a Combustível.

\begin{tabular}{|c|c|c|c|c|c|}
\hline Tipo & $\begin{array}{c}\text { Eletrólito } \\
\text { (espécie } \\
\text { transportada) }\end{array}$ & $\begin{array}{l}\text { Faixa de } \\
\text { Temp. } \\
\left({ }^{\circ} \mathrm{C}\right)\end{array}$ & Vantagens & Desvantagens & Aplicações \\
\hline $\begin{array}{l}\text { Alcalina } \\
\text { (AFC) }\end{array}$ & $\begin{array}{l}\mathrm{KOH} \\
\left(\mathrm{OH}^{-}\right)\end{array}$ & $60-90$ & $\begin{array}{l}\text { - Alta eficiência } \\
\text { (83\% teórica) }\end{array}$ & $\begin{array}{l}\text { - Sensível a } \mathrm{CO}_{2} \\
\text { - Gases ultra puros, sem } \\
\text { reforma do combustível }\end{array}$ & $\begin{array}{l}\text { - Espaçonaves } \\
\text { - Aplicações militares }\end{array}$ \\
\hline $\begin{array}{c}\text { Membrana } \\
\text { (PEMFC) }\end{array}$ & $\begin{array}{l}\text { Polímero: } \\
\text { Nafion }{ }^{\circledR} \\
\left(\mathrm{H}_{3} \mathrm{O}^{+}\right)\end{array}$ & $80-90$ & $\begin{array}{l}\text { - Altas densidade de } \\
\text { - Operação flexível }\end{array}$ & $\begin{array}{l}\text { - Custo da membrana } \\
\text { potência e eficiência } \\
\text { - Contaminação do } \\
\text { catalisador com CO }\end{array}$ & $\begin{array}{l}\text { - Veículos automotores } \\
\text { e catalisador } \\
\text { - Espaçonaves } \\
\text { - Mobilidade }\end{array}$ \\
\hline $\begin{array}{l}\text { Ácido } \\
\text { fosfórico } \\
\text { (PAFC) }\end{array}$ & $\begin{array}{l}\mathrm{H}_{3} \mathrm{PO}_{3} \\
\left(\mathrm{H}_{3} \mathrm{O}^{+}\right)\end{array}$ & $160-200$ & $\begin{array}{l}\text { - Maior desenvolvimento } \\
\text { tecnológico }\end{array}$ & $\begin{array}{l}\text { - Controle da porosidade } \\
\text { do eletrodo } \\
\text { - Sensibilidade a CO } \\
\text { - Eficiência limitada pela } \\
\text { corrosão }\end{array}$ & $\begin{array}{l}\text { - Unidades estacionárias } \\
\text { - Unidades estacionárias } \\
\text { (100 kW a alguns MW) } \\
\text { - Cogeração eletricidade/ } \\
\text { calor }\end{array}$ \\
\hline $\begin{array}{l}\text { Cerâmicas } \\
\text { (SOFC) }\end{array}$ & $\begin{array}{l}\mathrm{ZrO}_{2} \\
\left(\mathrm{O}^{2-}\right)\end{array}$ & $800-900$ & $\begin{array}{l}\text { - Alta eficiência } \\
\text { (cinética favorável) } \\
\text { - A reforma do combustível } \\
\text { pode ser feita na célula }\end{array}$ & $\begin{array}{l}\text { - Problemas de materiais } \\
\text { - Expansão térmica } \\
\text { - Necessidade de pré- } \\
\text { reforma }\end{array}$ & $\begin{array}{l}\text { - Unidades estacionárias } \\
\text { de } 10 \text { a algumas centenas } \\
\text { de } \mathrm{kW} \\
\text { - Cogeração eletricidade/ } \\
\text { calor }\end{array}$ \\
\hline
\end{tabular}

Atualmente, o desenvolvimento de células procura a não dependência das mesmas de gases puros para o combustível, mas sim de, por exemplo, gás natural ou mesmo metanol. Por sua vez, para o agente oxidante, o uso de ar atmosférico é preferível a oxigênio puro.

\section{AS REAÇÕES ANÓDICAS E CATÓDICAS. ELETROCATÁLISE}

As reações anódica (1) e catódica (2) representam, de uma maneira geral, a ruptura das ligações químicas entre dois átomos de hidrogênio e de oxigênio respectivamente. A ruptura das moléculas diatômicas $\mathrm{H}_{2}$ e $\mathrm{O}_{2}$ requerem uma energia de ativação da mesma ordem de grandeza de suas energias de formação, quando as reações são homogêneas e ocorrem em fase gasosa. Em células a combustível, entretanto, ambas as reações são heterogêneas e ocorrem na interface eletrodo/eletrólito, sendo catalisadas na superfície do eletrodo. Devido a esse fato, utiliza-se, nas células de baixa temperatura de operação, platina como catalisador tanto na reação anódica como na catódica ${ }^{1,2}$. A platina é dispersa, aleatóriamente, em partículas nanométricas na superfície interna de carvão ativo. O efeito catalítico no ânodo resumese na ruptura por adsorsão química da molécula de $\mathrm{H}_{2}$, enquanto no cátodo somente no enfraquecimento da ligação oxigênio/oxigênio, também por adsorsão química da molécula de $\mathrm{O}_{2}$. As etapas (4a) (4b) e (4c) descrevem a decomposição eletroquímica do hidrogênio.

$$
\begin{aligned}
& \mathrm{H}_{2} \leftrightarrow \mathrm{H}_{2} \text {,ads } \\
& \mathrm{H}_{2, \text { ads }} \leftrightarrow 2 \mathrm{H}_{\text {ads }} \\
& \mathrm{H}_{\text {ads }}+\mathrm{H}_{2} \mathrm{O} \leftrightarrow \mathrm{H}_{3} \mathrm{O}^{+}+\mathrm{e}^{-}
\end{aligned}
$$

As etapas envolvidas na redução do oxigênio são significativamente mais complicadas, tendo a formação de peróxido de hidrogênio como produto intermediário, e são mostradas a seguir:
$\mathrm{O}_{2} \leftrightarrow \mathrm{O}_{2}$, ads

$\mathrm{O}_{2, \text { ads }}+\mathrm{H}^{+}+\mathrm{e}^{-} \leftrightarrow \mathrm{O}_{2} \mathrm{H}_{\text {ads }}$

$\mathrm{O}_{2} \mathrm{H}_{\mathrm{ads}}+\mathrm{H}^{+}+\mathrm{e}^{-} \leftrightarrow \mathrm{H}_{2} \mathrm{O}_{2}$

$\mathrm{H}_{2} \mathrm{O}_{2}+2 \mathrm{H}^{+}+2 \mathrm{e}^{-} \leftrightarrow 2 \mathrm{H}_{2} \mathrm{O}$

Na Figura 2 é mostrada, por microscopia eletrônica de transmissão, a microestrutura de um catalisador de platina de uma célula a membrana polimérica. $\mathrm{Na}$ foto distinguem-se claramente os cristais hexagonais da parte grafitizada (do eletrodo de carvão ativo) e os cristais escuros (isolados) de platina.

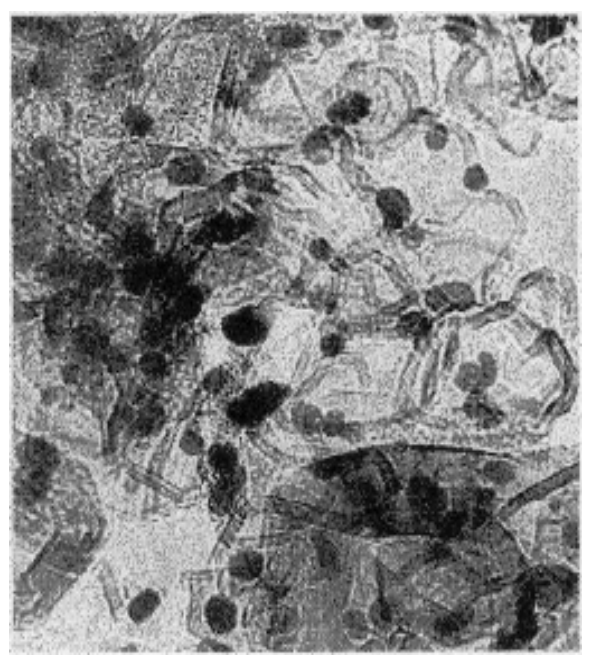

Figura 2. Microestrutura um catalisador de Pt obtida por microscopia eletrônica de transmissão (2.700.000X). As partículas de platina são os pontos escuros sobre o carbono grafitizado. (Fonte: Stoneheart Associates Inc.) 
Para células a combustível de alta temperatura de operação não há a necessidade da utilização de metais nobres como catalisadores, já que nesta faixa de temperaturas, o próprio metal do eletrodo torna-se suficientemente ativo. Assim, para as células a carbonato fundido, utiliza-se como material de eletrodo - e ao mesmo tempo eletrocatalisador - níquel para o ânodo (Figura 3, a esquerda) e óxido de níquel com incrustações de lítio para o cátodo, que é um semicondutor $p$ (Figura 3, a direita). No caso das células cerâmicas, utiliza-se um cermet de $\mathrm{Ni} / \mathrm{ZrO}_{2}$ como material do ânodo, ou seja, uma matriz de níquel metálico sintetizado, com óxido de zircônio finamente distribuído. Como material do cátodo utiliza-se manganato de lantânio dopado com estrôncio, $\mathrm{La}(\mathrm{Sr}) \mathrm{MnO}_{3}$.

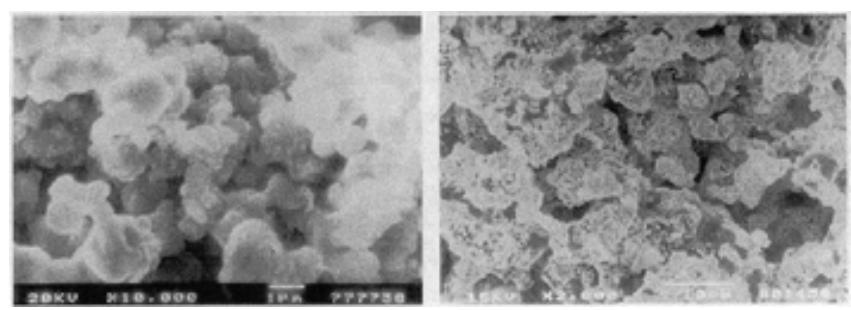

Figura 3. Microestruturas de eletrodos de células tipo MCFC, obtidas por microscopia eletrônica de varredura. Esquerda: ânodo de níquel sintetizado endurecido. Direita: cátodo de NiO.

\section{ELETRODOS DE DIFUSÃO GASOSA, UNIDADES MATRIZ/ELETRODO E EMPILHAMENTO DE CÉLULAS}

Eletrodos de difusão gasosa são uma estrutura porosa condutora de elétrons coerente do sistema eletrodo/eletrocatalisador ${ }^{1}$. A construção deste eletrodo tem como função a maximização da interface trifásica gás-líquido-sólido (exceto para as SOFC, que possuem eletrólito sólido), aumentando consideravelmente a velocidade dos processos eletródicos. Os eletrodos de difusão gasosa devem satisfazer no mínimo duas exigências importantes: (1) devem possuir alta atividade catalítica, a fim de se obter altas densidades de corrente e; (2) os poros, durante a operação do eletrodo, não podem apresentar forças capilares muito fortes, para não sugar todo o eletrólito, e a pressão do gás não deve ser muito alta, para que o eletrólito não seja totalmente expulso dos poros. Nestes dois extremos o eletrodo torna-se ineficiente. A superfície interna dos poros do eletrodo é contatada por um filme delgado do eletrólito, de modo que os poros relativamente grandes (diâmetros entre 0,1 a $1 \mu \mathrm{m})$ fiquem livres para a circulação/difusão dos gases de trabalho. Os eletrodos de difusão gasosa são extremamente delgados, podendo possuir, por exemplo, espessuras de $0,1 \mathrm{~mm} \mathrm{em}$ células de baixa temperatura de operação ou $0,5 \mathrm{~mm}$ em células de alta temperatura de operação.

Em células de baixa temperatura de operação, as partículas do eletrocatalisador estão numa faixa de distribuição de tamanho nanométrica, dispersas, geralmente, em partículas de carvão ativo de diâmetros entre 30 e 100 nm (ver Figura 2). Em células de alta temperatura de operação as partículas do eletrocatalisador (do próprio eletrodo) são da mesma ordem de grandeza ou maiores que as partículas de carvão ativo. A fabricação destes eletrodos baseia-se, na maioria dos casos, na fabricação de filmes precursores, que são obtidos a partir de uma pasta, como nos processos cerâmicos tradicionais (doctor-blade). Esta pasta contém, além do catalisador, um formador de poros e um ligante orgânico apropriado, por exemplo, um álcool polivinílico. O ligante dá sustentação intermediária ao filme, sendo mais tarde evaporado por aquecimento. Para a fabricação de eletrodos de difusão gasosa para células a membrana, deve-se antes contatar o catalisador com uma solução do eletrólito (Nafion $\left.{ }^{\circledR}\right)$. Quando o eletrólito está na forma líquida, como é o caso das células a ácido fosfórico e a carbonato fundido, não se pode, obviamente, formar um filme sólido portátil. Neste caso, o eletrólito é sugado por uma matriz porosa fixada entre os eletrodos. Nas células a ácido fosfórico, utiliza-se carbeto de silício, com diâmetro médio de $0,1 \mu \mathrm{m}$, como material para esta matriz. Nas células a carbonato fundido utiliza-se uma matriz de partículas de $\mathrm{LiAlO}_{2}$. A matriz também é fabricada na forma de filmes, obtendo-se, assim, as unidades eletrodo/matriz/eletrodo (MEA: Membrane/ Matrix Electrode Assembly), como mostrado na Figura 4.

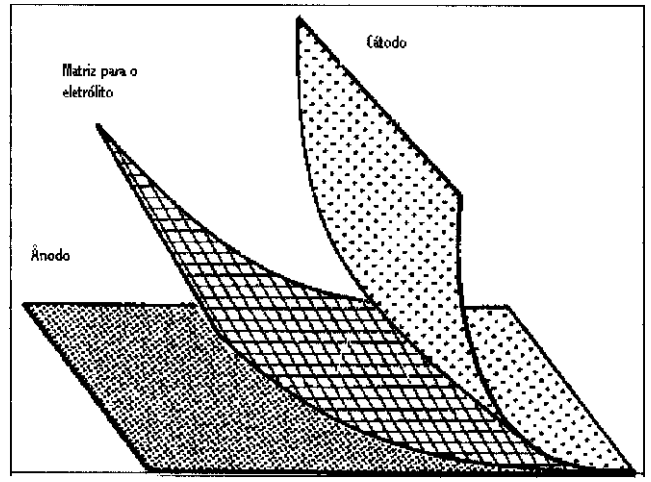

Figura 4. Unidade composta de ânodo, cátodo e matriz do eletrólito, fabricada na forma de filme delgado para células a carbonatos fundidos.

Após a montagem da unidade eletrodo/matriz na célula PEM, processa-se a retirada do ligante orgânico polimérico da matriz, por aquecimento. Este processo tem como efeito a fixação dos eletrodos e da matriz na célula. No caso das células a carbonato introduz-se o eletrólito também na forma de um filme, composto pela mistura de carbonato de lítio e potássio, que é posteriormente fundido. Nos outros tipos, após a introdução do eletrólito, procede-se a configuração final da célula in situ.

Células unitárias apresentam um potencial aberto de 1 a 1,2 $\mathrm{V}$ e liberam, sob solicitação de 0,5 a $0,7 \mathrm{~V}$ DC. Estes valores são, sob o ponto de vista prático, muito baixos. A necessidade de empilhamento em série de várias unidades de células $(200$ a 300), como mostrado na Figura 5, torna-se óbvia, a fim de se obter potenciais práticos da ordem de 150 a $200 \mathrm{~V}$.

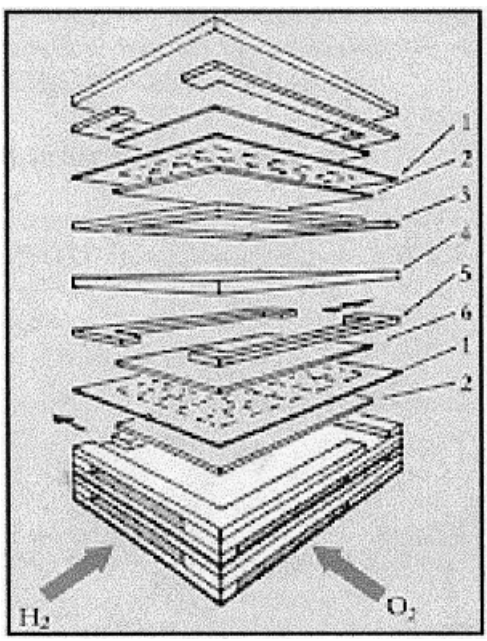

Figura 5. Montagem de um empilhamento de unidades de células a combustível. 1: Placa bipolar, 2: cátodo, 3: moldura do cátodo, 4: eletrólito, 5: moldura do ânodo, 6: ânodo. 


\section{A EFICIÊNCIA dAS CÉlulas A COMBUSTÍVEL}

O princípio das células a combustível foi descoberto por Sir Grove já em 1835. No final do século passado, Wilhelm Ostwald e Walther Nernst demonstraram a vantagem da combustão eletroquímica a frio em relação a produção de eletricidade pela máquina de calor/mecânica, que funciona sob o princípio de Carnot. A eficiência teórica $\eta$ de qualquer processo de produção de energia eletroquímica é obtida pelo quociente ${ }^{1}$ :

$\eta=\Delta \mathrm{G} / \Delta \mathrm{H}$

Na Figura 6 são mostrados valores de $\eta$ para a reação de combustão (reação 3) em fase gasosa em função da temperatura segundo o processo eletroquímico e o ciclo de Carnot. A eficiência teórica eletroquímica diminui de 86 a $70 \%$ na faixa de temperaturas de 100 a $1000^{\circ} \mathrm{C}$. A eficiência de Carnot, por sua vez, eleva-se de 0 a $70 \%$ na mesma faixa e somente a temperaturas superiores a $1000^{\circ} \mathrm{C}$ é maior que a eficiência teórica eletroquímica. Portanto, células a combustível a hidrogênio apresentam uma eficiência teórica significativamente maior que máquinas de Carnot, principalmente a baixas temperaturas. $\mathrm{Na}$ Figura 6 também é mostrada, comparativamente, a curva da conversão eletroquímica do metano. Neste caso, a eficiência teórica encontra-se muito próxima de $100 \%$ em toda a faixa de temperaturas mostrada. O metano torna-se, assim, o armazenador de energia primário de preferência para células a combustível.

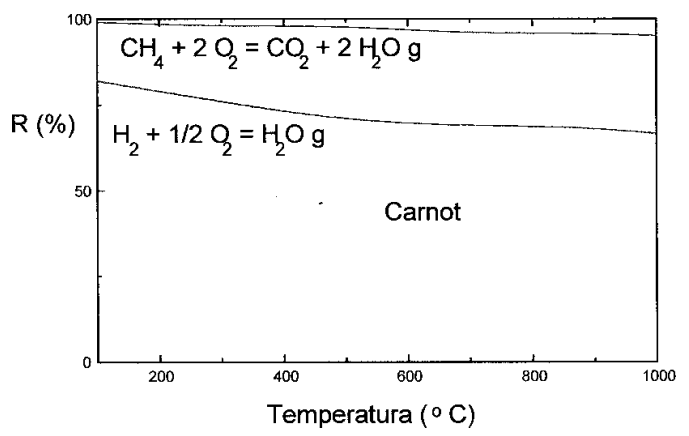

Figura 6. Dependência do rendimento teórico com a temperatura da conversão eletroquímica do hidrogênio, do metano e no ciclo de Carnot.

\section{A CÉlula A ÁCIDO FOSFórico}

Ostwald e Nernst não conseguiram, na virada do século, uma aplicação prática para o princípio das células a combustível, principalmente porque, naquela época, os principais problemas de materiais ainda não tinham sido solucionados ou até mesmo não tinham sido equacionados. A primeira célula a combustível funcional somente foi construída na década de 30 , por Bacon, que operava a $200^{\circ} \mathrm{C}$, sob pressão, utilizando eletrólito alcalino. Nos anos 50, Broers e Ketelaar, na Holanda, realizaram experimentos com células a carbonato fundido. Mais tarde, Broers desenvolveu, na NASA norte-americana, a primeira célula a membrana polimérica, que, entretanto, devido à instabilidade da membrana, não correspondeu às expectativas. Logo após, foram desenvolvidas as células alcalinas para o programa espacial norte-americano. Estas células são entretanto demasiadamente custosas, não sendo viável a sua utilização para aplicações terrestres.

Somente no final dos anos 60 teve início o desenvolvimento das células a ácido fosfórico, PAFC (Phosphoric Acid Fuel Cell), pela firma United Technology Corporation, fato que representou um significativo progresso tecnológico. Este tipo de célula, ao contrário das células alcalinas, não são sensíveis ao dióxido de carbono do ar e mesmo pouco sensíveis ao monóxido de carbono, que envenena o catalisador, permitindo um teor de até $1 \%$ de $\mathrm{CO}$ no gás de alimentação anódico a $200^{\circ} \mathrm{C}$. O desenvolvimento desta células tinha, desde o início, o objetivo de conquistar o importante mercado das usinas queimadoras de metano.

Nos anos 80, foi realizada, nos Estados Unidos, a primeira tentativa de campo com um sistema de 40 unidades de células a ácido fosfórico, alimentadas com gás natural, com uma potência elétrica de $40 \mathrm{~kW}$. Uma condição importante para este experimento foi a miniaturização da tecnologia de reforma e conversão do gás natural, reações (7) e (8).

$\mathrm{CH}_{4}+\mathrm{H}_{2} \mathrm{O} \rightarrow \mathrm{CO}+3 \mathrm{H}_{2}$
$\mathrm{CO}+\mathrm{H}_{2} \mathrm{O} \rightarrow \mathrm{CO}_{2}+\mathrm{H}_{2}$

Enquanto um processo de reforma industrial consome 30.000 $\mathrm{m}^{3} / \mathrm{h}$ de gás natural, uma bateria de células a combustível de $200 \mathrm{~kW}$, com uma eficiência total de $40 \%$, consome apenas 50 $\mathrm{m}^{3} / \mathrm{h}$ do mesmo combustível.

Como mostrado na Figura 7, uma instalação de células a combustível, para o consumo de gás natural, é composta de:

- sistema de processamento químico (reforma) do gás natural, onde o metano é convertido numa mistura de gases, chamada de gases de síntese, contendo hidrogênio e dióxido de carbono no proporção de aproximadamente $4: 1$, com muito pouco monóxido de carbono $(<1 \%)$;

- empilhamento das unidades de células a combustível, que oxidam o hidrogênio do gás de síntese nos ânodos e reduzem o oxigênio do ar nos cátodos. As células consomem cerca de $80 \%$ do combustível e cerca de $50 \%$ do oxigênio do ar;

- conversor, que converte a corrente contínua produzida pelas células em valores de rede de corrente alternada, com uma frequência adequada, por exemplo $220 \mathrm{~V}$ e $50 \mathrm{~Hz}$ ou $110 \mathrm{~V}$ e $60 \mathrm{~Hz}$;

- trocador de calor e queimador, onde, por um lado, se pode aproveitar o calor residual das células internamente ou externamente e, por outro lado, pode-se queimar o combustível não consumido nas células para a reforma do gás.

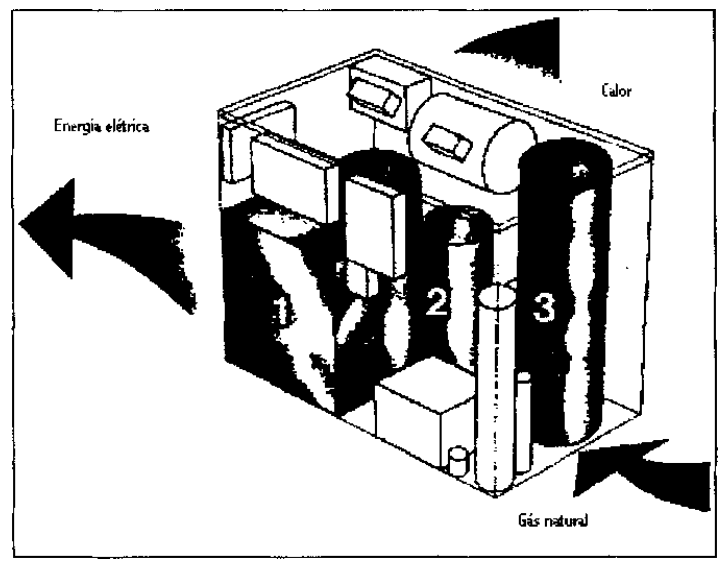

Figura 7. Esquema da montagem de um sistema de células a combustível tipo PAFC a gás natural. 1: Conversor DC/AC, 2: processamento do combustível e 3: unidades de células a combustível.

Ainda hoje, existe no mundo todo um único fabricante comercial, ONSI Corp., deste tipo de instalação, acondicionada em um container (Figura 7). Aproximadamente 100 unidades do tipo PC 25, com uma potência elétrica de $200 \mathrm{~kW}$ cada uma estão em operação atualmente e 200 outras unidades devem ser comercializadas nos próximos anos, quando, acredita-se, o preço do $\mathrm{kW}$ deverá ser reduzido de US\$ 3.000 a US\$ 2.000. Estas unidades apresentam uma eficiência global inicial de $42 \%$. 
Na Alemanha, por exemplo, estão em operação 6 unidades do tipo PC 25 de $200 \mathrm{~kW}$ de potência elétrica. A experiência é bastante positiva, embora o custo do $\mathrm{kW}$ ainda seja muito alto, por volta de US\$ 3.000. Tentativas de outros fabricantes de grande porte ainda não alcançaram produtos comercializáveis, como por exemplo no Japão, onde foram construídas e testadas unidades de alguns MW até um máximo de $11 \mathrm{MW}$ de potência elétrica. As células a combustível de elevadas temperaturas de operação tiveram, no mesmo período um desenvolvimento tecnológico muito mais lento, devido, principalmente a problemas de materiais.

\section{CÉlulas de ALTA TEMPERATURA DE OPERAÇÃo}

As células de alta temperatura de operação são classificadas em dois tipos: MCFC (Molten Carbonate Fuel Cell) ${ }^{3}$ e SOFC (Solid Oxide Fuel Cell). Estas células apresentam algumas vantagens em relação a outros tipos de células combustíveis, como facilidade de gerenciamento do eletrólito (SOFC) e a não necessidade do uso de metais nobres como catalisadores. Também possuem maiores valores de eficiência teórica de conversão, e têm uma alta capacidade de coprodução eletricidade/calor. A elevada temperatura de operação favorece a cinética das reações eletródicas e permite a reforma do combustível (por ex.: hidrocarbonetos ou gás natural) no próprio corpo da célula. Então, sistemas energéticos baseados em células combustíveis cerâmicas (SOFC) podem, potencialmente, ser de operação simples e mais eficientes que os demais. Deve-se ainda salientar outra característica importante destas células, que é o fato de que todos os seus componentes são sólidos, podendo-se utilizar processos de fabricação em camadas finas e compactas, com conFigurações flexíveis, aumentando desta forma a performance deste tipo de célula em particular.

Tecnologicamente, a utilização da concepção destas células encontra algumas limitações quanto à seleção e processamento dos materiais envolvidos. Este fato deve-se, principalmente, às altas temperaturas utilizadas, que favorecem processos de corrosão, tensões térmicas, fadiga dos distintos componentes, entre outros. Estes aspectos têm motivado incessantes esforços por parte da comunidade científica no sentido de se estudar e desenvolver materiais e processos que possam atender a especificações para esta aplicação.

As etapas envolvidas para a célula tipo SOFC são:

$$
\begin{aligned}
& \mathrm{CO}+\mathrm{H}_{2} \mathrm{O} \rightarrow \mathrm{CO}_{2}+\mathrm{H}_{2} \text { (no ânodo) } \\
& \mathrm{O}^{2-}+\mathrm{H}_{2} \rightarrow \mathrm{H}_{2} \mathrm{O}+2 \mathrm{e}^{-} \text {(na interface ânodo/eletrólito) } \\
& \mathrm{O}_{2}+4 \mathrm{e}^{-} \rightarrow 2 \mathrm{O}^{2-} \quad \text { (no cátodo) } \\
& ------------\mathrm{H}_{2} \mathrm{O} \\
& \mathrm{H}_{2}+1 / 2 \mathrm{O}_{2} \rightarrow \mathrm{HO}_{2} \quad \text { (total) }
\end{aligned}
$$

A empresa alemã MTU, de Friedrichshafen, desenvolveu, recentemente, uma célula a carbonato fundido (MCFC) de $300 \mathrm{~kW}$ de potência elétrica, onde por simplificações radicais da engenharia e tecnologia da unidade, pôde-se reduzir drasticamente os custos globais, eliminando-se a necessidade do custoso trocador de calor de alta temperatura. A reforma endotérmica do gás natural é realizada na própria coluna de unidades de células, eliminando-se o caro reformador e, ao mesmo tempo, resfriando as células. Em Santa Clara, nos Estados Unidos, foi construído um conjunto de unidades de células MCFC, de $2 \mathrm{MW}$ de potência. Este programa foi muito importante sob o ponto de vista tecnológico, mas sem resultados comerciais. Também recentemente foram desenvolvidas pequenas instalações de células cerâmicas do tipo HEXIS (Heat Exchange Solid Oxide Fuel Cell), de apenas $10 \mathrm{~kW}$ de potência elétrica, para o aquecimento e fornecimento de energia doméstico. Estas unidades possuem uma configuração cilíndrica.

\section{A CÉlula a membrana POlimérica}

Células de baixa temperatura de operação, que utilizam uma membrana polimérica como eletrólito, também chamadas PEMFC (Proton Exchange Membran Fuel Cell), são as mais promissoras como alternativa para motores a combustão, por ser robustas e de fácil acionamento e desligamento, além das vantagens inerentes como alta eficiência com baixa emissão de poluentes. Devido à baixa temperatura de operação, e, mesmo utilizando-se ar como alimentação do cátodo, tem-se emissão zero para $\mathrm{NO}_{\mathrm{x}}$. As células de baixa temperatura também se aplicam a unidades estacionárias. Atualmente, o fator determinante para a sua entrada no mercado é, ainda, o seu custo ${ }^{4,5}$.

As células que utilizam uma membrana polimérica como eletrólito são conhecidas desde os tempos iniciais das pesquisas espaciais. Entretanto, somente com a introdução da membrana de Nafion ${ }^{\circledR}$, mais resistente quimicamente, obteve-se sucesso em relação ao desempenho a longo prazo. Esta membrana de ionômero perfluorado foi desenvolvida inicialmente para a eletrólise cloro/ soda e é composta por um polímero perfluorado de tetrafluorpolietileno, onde, num de seus lados, um éter faz a ligação com um ácido etil sulfônico perfluorado (grupo ionogênico).

A estrutura da membrana Nafion ${ }^{\circledR}$ é dada por:

$$
\begin{aligned}
& {\left[-\left(-\mathrm{CF}_{2}-\mathrm{CF}_{2}-\right)_{n}-\mathrm{CF}_{2}-\mathrm{CF}-\right]_{\mathrm{x}}} \\
& \text { I } \\
& \text { (O- } \left.\mathrm{CF}_{2}-\mathrm{CF}-\right)_{\mathrm{m}}-\mathrm{O}-\mathrm{CF}_{2}-\mathrm{CF}_{2}-\mathrm{SO}_{3}^{-}\left(\mathrm{Na}^{+}, \mathrm{H}^{+}\right) \\
& 1 \\
& \mathrm{CF}_{3}
\end{aligned}
$$

onde, $\mathrm{n}=5$ a $13 ; \mathrm{x} \approx 1000$ e $\mathrm{m} \approx 1$. As pontas das cadeias, onde se encontra os grupo sulfônico, formam uma espécie de bolha na estrutura, que se incha, em contato com a água ou vapor d'água. Estas bolhas, que são interligadas, são responsáveis pela condução de prótons e água pela membrana, sob o efeito de um campo elétrico. Esta estrutura consiste, entretanto, em um filme relativamente rígido e estável mecanicamente.

Os eletrodos das células de primeira geração constituíam-se de platina finamente dispersa, tipo platinmohr. Este eletrodo era produzido por um processo de difusão/precipitação muito dispendioso, onde um agente redutor (hidrazina) difundia-se em contracorrente com uma solução hexacloroplatinada (por ex.: $\mathrm{Na}_{2} \mathrm{PtCl}_{6}$ ), provocando, sob controle da velocidade de difusão, a precipitação da platina finamente dividida sobre a superfície da membrana. Esta platina era, então, fortalecida eletroquimicamente. A carga de platina destas células era muito alta, de alguns miligramas por centímetro quadrado. $\mathrm{O}$ uso comercial deste tipo de célula era inimaginável.

A mudança de cenário veio com a utilização de carvão ativo, ativado com platina como eletrocatalisador. Seguindo a idéia de Raistrick ${ }^{6}$, Gottesfeld ${ }^{7}$ pôde mostrar, no inicio dos anos 90, que se podia utilizar, mais eficientemente, a superfície da platina sobre carvão ativo, como eletrocatalisador, quando se contata (molha) a superfície interna do carvão ativo com o ionômero da membrana, possibilitando que se utilize soluções de Nafion ${ }^{\circledR}$ (por exemplo: um álcool isopropílico), para embeber o carvão ativo, que contém a platina. Após a evaporação do solvente, a superfície interna do carvão ativo, que também contém nanocristais de platina, fica em contato com o eletrólito $\left(\right.$ Nafion $\left.{ }^{\circledR}\right)$ e pode, então, ser aproveitada como catalisador, já que os gases reagentes se dissolvem em Nafion ${ }^{\circledR} \mathrm{e}$, por difusão, alcançam os cristais de platina. 


\section{AUTOMÓVEIS MOVIDOS A CÉLULA A MEMBRANA POLIMÉRICA}

A tentativa de se produzir um automóvel movido a célula a combustível não é nova. Kordesch ${ }^{8}$ foi o primeiro a construir um carro deste tipo, já no final dos anos 60. No início dos anos 70, em Dresden, Schwabe e colaboradores montaram um ciclomotor com células movidas a hidrazina e posteriormente um microônibus VW, testado com sucesso até meados dos anos 90. Todos estes veículos utilizavam células alcalinas.

Técnicos da Universidade de Georgetown construíram, no início dos anos 90, o primeiro ônibus urbano movido a célula a combustível do tipo PAFC (a ácido fosfórico), utilizado no transporte público. Como combustível fez-se uso do metano, estocado em tanques sob pressão, que sofria reforma e conversão no próprio veículo. Antes que surgisse uma pequena frota deste tipo de veículo, a empresa canadense Ballard mostrou que células tipo PEMFC, movidas a hidrogênio, eram mais adequadas a esta aplicação automotiva, que as células tipo PAFC. Esta comprovação baseia-se, por um lado, na maior densidade de potência da PEMFC, mas acima de tudo, na sua melhor dinâmica, tornando desnecessária a instalação de baterias adicionais para a ignição do veículo.

A empresa canadense Ballard desenvolveu, com sucesso, um bloco de células tipo $275 \mathrm{HP}$, de $200 \mathrm{~kW}$ de potência elétrica, para a eletrotração de ônibus. A principal diferença para os ônibus convencionais é o teto mais elevado, onde estão alojados os tanques de pressão (200 bar) para hidrogênio. As empresas Ballard Automotive, DaimlerChysler e Ecostar (Ford) já possuem 6 ônibus em Chicago nos Estados Unidos e 3 em Vancouver no Canadá operando com células a combustível movidos a hidrogênio e pretendem, já em 2000, iniciar a produção em série deste tipo de veículo.

Automóveis elétricos movidos a PEMFC são veículos de emissão zero, ZEV (Zero Emission Vehicles), segundo a rígida norma regulamentar do estado da Califórnia nos EUA, desde que utilizem hidrogênio como combustível, ou mesmo um gás rico em hidrogênio, mas sem reforma e conversão de metano ou metanol a bordo do próprio veículo. Segundo esta norma, devese aumentar gradativamente a porcentagem de veículos de emissão zero nas ruas da Califórnia. A empresa Daimler-Benz alemã, em cooperação com a empresa Ballard canadense, desenvolveu não só um ônibus movido a PEMFC, como também vem executando várias etapas para o desenvolvimento de um automóvel de passeio viável, movido a célula de membrana polimérica. A base para esta decisão foi a resposta positiva para a pergunta da viabilidade econômica da tração automotiva a PEMFC, comparativamente a motores de combustão interna. Como resultado de seus esforços, esta empresa apresentou ao público dois automóveis a PEMFC, movidos a hidrogênio, o NECAR I e o NECAR II, além do NECAR III, movido a metanol, apresentado no Salão Internacional do Automóvel na Alemanha, em 1997. Na Figura 8 são mostrados os veículo NECAR I, II e III. Enquanto que NECAR I não tem a funcionalidade de um automóvel como conhecemos, já que está quase totalmente preenchido pelos equipamentos (conjunto de células, tanques de hidrogênio, etc.), o modelo NECAR II (tipo Kombi), apresentado em 1996, já pode transportar 5 pessoas além do motorista. Os cilindros de hidrogênio a pressão são alojados no teto e o conjunto de células embaixo dos bancos traseiros. $\mathrm{O}$ desenvolvimento seguinte, o modelo NECAR III, de quatro lugares e $50 \mathrm{~kW}$ de potência, não necessita dos cilindros de hidrogênio e tem o metanol como combustível líquido, que é convertido em hidrogênio a bordo. Já em 1999 a DaimlerChrysler lançou o NECAR IV, em Washington, movido a hidrogênio líquido, com $70 \mathrm{~kW}$ de potência e autonomia de $450 \mathrm{~km}$. Este veículo tem por base o "Classe A" da Mercedes-Benz, cuja produção do similar convencional teve início no Brasil desde a recente inauguração da montadora em Minas Gerais.

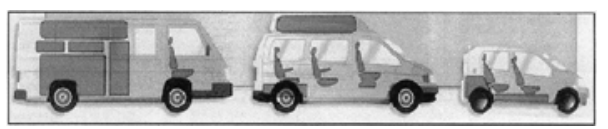

Figura 8. Representação esquemática das diferentes etapas de desenvolvimento do automóvel NECAR da Daimler Benz AG, movido a célula a combustível.

Atualmente, quase todos os grandes fabricantes de automóveis de passeio do mundo estão interessados no desenvolvimento de veículos elétricos, movidos a célula a combustível. Vários desenvolvimentos de protótipos estão em andamento, podendo ser citados o da Toyota, RAV4-FCEV, um utilitário-esportivo; da Opel (GM), Zafira, uma minivan com plataforma do Astra; da Ford. P2000, também um utilitário-esportivo com plataforma do Mondeo. Só estas três montadoras planejam ter, no ano 2003, 50 automóveis e 20 ou 25 ônibus rodando na Califórnia, nos Estados Unidos. Outros programas são desenvolvidos pela Honda, Jeep, etc. Para informações mais detalhadas destes projetor consultar: http://www.dodfuelcell.com/helpfulsites.html

\section{UMA ALTERNATIVA REALISTA AO MOTOR OTTO?}

O uso de hidrogênio como combustível para a eletrotração, em substituição aos motores de combustão interna (Otto), não é muito confortável, pois requer, para o seu armazenamento, técnicas complicadas como cilindros de alta pressão. Mesmo na forma líquida ou ainda na forma de um hidreto metálico, há sempre a exigência de severas medidas de segurança. Além disso, não existe hoje nem uma rede de distribuição, nem uma capacidade de produção suficientes para a demanda de uma grande frota deste tipo de veículo. O metanol é, então, muito mais adequado como armazenador de energia. Também possui a vantagem de que a sua reforma e conversão a bordo são mais simples que para a gasolina ou metano, já que apresenta uma maior reatividade relativa. A reforma do metanol processa-se já a $200^{\circ} \mathrm{C}$ (equação 13 ), enquanto que a reforma do metano processa-se a $1000^{\circ} \mathrm{C}$.

$\mathrm{CH}_{3} \mathrm{OH}+\mathrm{H}_{2} \mathrm{O} \rightarrow \mathrm{CO}_{2}+3 \mathrm{H}_{2}$

A reforma catalítica do metanol e a conversão produzem o chamado gás de síntese, que ainda possui cerca de $1 \%$ de $\mathrm{CO}$, um potente veneno do catalisador da célula $(\mathrm{Pt})$. Para que esse gás possa ser utilizado na célula deve-se reduzir o teor de $\mathrm{CO}$ para valores próximos de $10 \mathrm{ppm}$. Para este fim, duas possibilidades podem ser consideradas: metanização seletiva com contato com Pt (o inverso da reforma do metano):

$\mathrm{CO}+3 \mathrm{H}_{2} \rightarrow \mathrm{CH}_{4}+\mathrm{H}_{2} \mathrm{O}$

ou oxidação catalítica e seletiva do monóxido de carbono:

$\mathrm{CO}+1 / 2 \mathrm{O}_{2} \rightarrow \mathrm{CO}_{2}$

que pode ser processada no gás de síntese com a adição de uma porcentagem de ar com contato com Pt. A metanização seletiva (14) não é desejada, pois $\mathrm{CO}_{2}$ também sofre metanização paralelamente. Na presença de oxigênio pode-se, entretanto, suprimir a reação (14), escolhendo-se a oxidação catalítica, isto é, devido a co-adsorção de $\mathrm{CO}$ e $\mathrm{O}_{2}$, a reação (14) não é mais possível (efeito cinético). Entretanto, a reação (15) é acompanhada de oxidação catalítica de hidrogênio. Assim, sacrifica-se uma pequena porcentagem do hidrogênio disponível, quando se deseja aproximar a meta de 10 ppm de CO. O desenvolvimento de um catalisador para o ânodo que possa oxidar hidrogênio efetivamente na presença de até $100 \mathrm{ppm}$ de CO resolveria este dilema. Esta meta 
ainda não foi efetivamente alcançada. Entretanto, existem tentativas promissoras de utilização de sistemas de catalisadores binários. Como exemplo, são mostradas na Figura 9 várias curvas da variação do potencial com a densidade de corrente de células tipo PEMFC, que utilizam tanto hidrogênio puro quanto hidrogênio com $150 \mathrm{ppm}$ de $\mathrm{CO}$ como combustível e uma carga anódica de catalisador de $0,4 \mathrm{mg} / \mathrm{cm}^{2}$. O catalisador a platina pura sobre carvão ativo é praticamente desativado na presença de $150 \mathrm{ppm}$ de CO. Entretanto, a utilização de um catalisador binário Ru/Pt (1:1) aumenta significativamente a atividade catalítica, reconhecida na elevação do potencial da célula. A adição de Sn também reduz significativamente o envenenamento do catalisador.

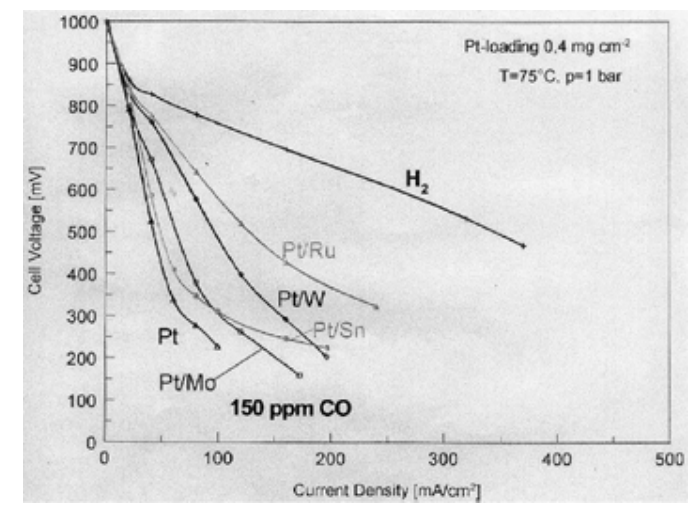

Figura 9. Curvas de densidade de corrente versus potencial de células tipo PEMFC com diferentes catalisadores no ânodo e alimentação de hidrogênio puro ou contendo $150 \mathrm{ppm}$ de CO. Para a operação com hidrogênio puro as curvas são todas idênticas.

Obviamente seria muito interessante o desenvolvimento de uma PEMFC, que efetuasse a conversão direta de metanol eletroquimicamente, dispensando todas as etapas intermediárias de reforma e purificação. Na realidade isso é possível, mas apenas em experimentos de curta duração, com densidades de corrente e de potência significativas. Após alguns minutos ocorre o envenenamento do catalisador, já que a superfície ativa do catalisador é ocupada por CO. Neste caso tem-se a chamada DMFC (Direct Methanol Fuel Cell) e as etapas envolvidas, para operação com $\mathrm{O}_{2}$ são:

$$
\begin{aligned}
& \text { Ânodo: } \mathrm{CH}_{3} \mathrm{OH}+7 \mathrm{H}_{2} \mathrm{O} \rightarrow \mathrm{CO}_{2}+6 \mathrm{H}_{3} \mathrm{O}^{+}+6 \mathrm{e}^{-} \\
& \text {Cátodo: } \quad 3 / 2 \mathrm{O}_{2}+6 \mathrm{H}_{3} \mathrm{O}^{+}+6 \mathrm{e}^{-} \rightarrow 9 \mathrm{H}_{2} \mathrm{O} \\
& ---------------------- \\
& \text { Total: } \quad \mathrm{CH}_{3} \mathrm{OH}+3 / 2 \mathrm{O}_{2} \rightarrow \mathrm{CO}_{2}+2 \mathrm{H}_{2} \mathrm{O}
\end{aligned}
$$

Deve-se, então tentar desenvolver um sistema de catalisadores, capaz de oxidar metanol, sem ser suficientemente afetado por CO. Até o momento tem-se o sistema binário $\mathrm{Ru} / \mathrm{Pt}$ (1:1) como o mais apropriado. Entretanto, deve-se empregar uma quantidade de catalisador (metais nobres) dez vezes maior que a necessária na conversão direta de hidrogênio, para se atingir valores equivalentes de densidade de potência. Este fato não é tolerável economicamente para a eletrotração automotiva. Um outro problema atual é a alta permeabilidade de membrana (eletrólito) por metanol, gerando um tipo de "curto circuito" da célula.

Por outro lado sabe-se que, um aumento da temperatura de operação da célula de (hoje) $90^{\circ} \mathrm{C}$ a aproximadamente $200^{\circ} \mathrm{C}$ diminuiria consideravelmente os problemas de cinética de eletrodo presentes na oxidação anódica direta do metanol. A razão disso é o enfraquecimento da ligação de adsorsão de CO na platina a alta temperatura e a aceleração considerável de todas as etapas químicas da oxidação anódica do metanol. Mas a $200^{\circ} \mathrm{C}$ não se pode mais utilizar a membrana Nafion ${ }^{\circledR}$ como eletrólito, pois ela secaria e perderia sua condutividade iônica. A chave para a conversão direta de metanol está, provavelmente, não só no desenvolvimento de novos sistemas de catalisadores, mas também na introdução de membranas ácidas de troca iônica, que, mesmo a elevada temperatura possuam uma significativa condutividade iônica?

\section{EXISTE UMA TECNOLOGIA DE CÉLULAS A COMBUSTÍVEL?}

\section{Resposta e perspectivas}

O desenvolvimento da tecnologia de células a combustível tem revezado, nos últimos 30 anos, alguns momentos de euforia e de decepção ${ }^{2}$. Freqüentemente falou-se da sua total inviabilidade como, por exemplo, há 15 anos, pela indústria alemã. Muito dinheiro já foi gasto neste desenvolvimento - no mínimo US\$ 1 bilhão - e o que obteve-se disso tudo? Pode-se, claro, empregá-la nas naves espaciais, com um alto padrão técnico e alta confiabilidade, mas esta tecnologia faz uso das células alcalinas, que não têm futuro para aplicações terrestres. Como tecnologia já estabelecida e apresentável, pode-se citar os sistemas a ácido fosfórico da empresa ONSI. Mas poder-seá falar de um sucesso econômico real somente quando outros concorrentes oferecerem sistemas semelhantes no mercado. As perspectivas das células de alta temperatura de operação certamente não são ruins, mas ainda não existe nenhuma oferta deste tipo de sistema no mercado.

A tecnologia de células a membrana deve ser analisada de um modo bem diferente. O seu mercado principal é o dos veículos elétricos não poluentes e não o da geração de eletricidade/calor em unidades estacionárias de grande/médio portes. Para este fim ainda é necessário um desenvolvimento adicional. O fato de que uma importante montadora automobilística tem equipado não só ônibus, mas também carros de passeio com células tipo PEMFC e, muito além disso, tem uma meta já anunciada de que em 8 anos $2 \%$ de sua produção serão veículos movidos a PEMFC, não permite aos autores deste artigo duvidar do futuro - e do mercado - deste tipo de tecnologia.

\section{CÉlulas a COMBUSTÍVEL NO BRASIL}

Desde o final da década de 70 vem sendo realizadas algumas atividades na área de células a combustível no Brasil. Várias instituições, como a Universidade Federal do Ceará; a Universidade Federal do Rio de Janeiro; o Instituto de Pesquisas Tecnológicas (IPT) de São Paulo e o grupo de Eletroquímica de São Carlos (USP) ${ }^{10}$, já se dedicaram ao estudo direta ou indiretamente deste tipo de tecnologia. Destes grupos todos, salienta-se o grupo de eletroquímica de São Carlos (USP), que desenvolve, com sucesso, desde 1981, com um corpo de pesquisadores permanente, componentes e protótipos de células a combustível.

Mais recentemente, em meados de 1998 iniciou-se no IPEN/CNEN-SP um projeto institucional de caráter acadêmico e tecnológico em células combustíveis, segmentado em dois grupos: PEMFC, com a colaboração da Universidade Técnica de Darmstadt, Alemanha e SOFC, adequado ao perfil do Departamento de Engenharia e Ciência dos Materiais deste instituto, com colaboração prevista com o Riso National Laboratory, em Roskilde, Dinamarca. O enfoque inicial do grupo de estudos das células a membrana será a utilização de outro álcool além do metanol, como por exemplo o etanol, que também é um combustível líquido de fácil obtenção e baixo custo relativo. Etanol torna-se, particularmente atrativo como combustível alternativo para um país como o Brasil, 
que já possui uma tecnologia para a sua produção e uma infraestrutura bem estabelecidas, voltadas a indústria automobilística. A introdução da então chamada DEFC (Direct Ethanol Fuel Cell) para a eletrotração automotiva poderia ser imediata, sem grandes modificações na infra-estrutura já existente. Deve-se considerar ainda o caráter de fonte de energia renovável oferecida pela obtenção de etanol em grandes quantidades a partir da fermentação da cana de açúcar, de fácil cultivo em nosso país.

Entretanto, existem ainda muitos desafios nesta área de aplicação. Para obter eficiências significativas com este combustível, neste tipo de sistema, deve-se operar a célula a temperaturas mais elevadas, como já exposto neste artigo. Enquanto não houver a disponibilidade de um novo material polimérico com todas as características necessárias, pode-se, realizar, por tempo de operação limitado, estudos eletrocatalíticos com polímeros que possuem uma boa condutividade iônica a $200^{\circ} \mathrm{C}$, como solução transitória. Um eletrólito polimérico, deste tipo, foi sugerido por Savinell e colaboradores ${ }^{11,12,13,14}$ para aplicações em DMFC, o polibenzimidazol, dopado com ácido (PBI). Trabalhos recentes destes autores investigaram, nos Estados Unidos, a oxidação direta de álcoois, em células que utilizam membranas de PBI, dopadas com $\mathrm{H}_{3} \mathrm{PO}_{4}$, como eletrólito. Sugere-se, então, o seguinte processo de oxidação envolvendo 2 elétrons, com a formação de acetaldeído:

$\mathrm{CH}_{3} \mathrm{CH}_{2} \mathrm{OH} \rightarrow \mathrm{CH}_{3} \mathrm{CHO}+2 \mathrm{H}^{+}+2 \mathrm{e}^{-}$

Acetaldeído dietilacetal pode ser formado por catálise ácida segundo a reação:

$$
\mathrm{CH}_{3} \mathrm{CHO}+2 \mathrm{CH}_{3} \mathrm{CH}_{2} \mathrm{OH} \leftrightarrow \mathrm{CH}_{3} \mathrm{CH}\left(\mathrm{OCH}_{2} \mathrm{CH}_{3}\right)_{2}+\mathrm{H}_{2} \mathrm{O}(20)
$$

$\mathrm{Na}$ presença de água a reação (20) é deslocada fortemente para a esquerda, observando-se apenas traços de acetaldeído dietilacetal, para uma alimentação no ânodo contendo água. A distribuição relativa de $\mathrm{CO}_{2}$ é muito baixa comparada à oxidação do metanol (90 a 100\%). A reação global para a oxidação do etanol a $\mathrm{CO}_{2}$ pode ser assim formulada:

$$
\mathrm{CH}_{3} \mathrm{CH}_{2} \mathrm{OH}+3 \mathrm{H}_{2} \mathrm{O} \rightarrow 2 \mathrm{CO}_{2}+12 \mathrm{H}^{+}+12 \mathrm{e}^{-}
$$

A água fornece, então, o oxigênio necessário para a reação (21) ocorrer. Comparando-se a porcentagem de $\mathrm{CO}_{2}$ produzida pela oxidação de metanol com a de etanol, conclui-se que a quebra de uma ligação C-C no caso do etanol desempenha um papel importante na formação de $\mathrm{CO}_{2}$. Para uma máxima utilização do combustível deseja-se uma oxidação total do etanol a $\mathrm{CO}_{2}$, entretanto, sob o ponto de vista ambiental, a formação de etanal é preferível, já que, comparado ao $\mathrm{CO}_{2}$ e ao formaldeído, é significativamente menos tóxico, além de não se acumular nem em espécies vivas nem no meio ambiente, pois é passível de degradação biológica. Entretanto, antes da utilização de etanol como um combustível alternativo tornar-se praticável, deve-se aumentar consideravelmente o rendimento de $\mathrm{CO}_{2}$, durante a oxidação direta do etanol, para se elevar a eficiência da conversão de energia química em elétrica neste tipo de célula a combustível. O caminho mais adequado a se seguir, tendo-se em vista este objetivo, é a investigação de novos eletrocatalisadores mais seletivos para este sistema.

A opção de utilização indireta de etanol para a produção de hidrogênio, pode ser também considerada, numa etapa posterior do projeto. Como ponto de partida tem-se a reação inversa, ou seja, partir da reação catalítica de formação de etanol:

$2 \mathrm{CO}+4 \mathrm{H}_{2} \leftrightarrow \mathrm{CH}_{3} \mathrm{CH}_{2} \mathrm{OH}+\mathrm{H}_{2} \mathrm{O}$

seguida da reação de conversão de deslocamento:

$\mathrm{CO}+\mathrm{H}_{2} \mathrm{O} \leftrightarrow \mathrm{H}_{2}+\mathrm{CO}_{2}$
Além disso, deve-se adicionar uma etapa de oxidação catalítica do CO não reagido, a fim de se reduzir sua concentração a valores menores de $100 \mathrm{ppm}$. Todas estas etapas químicas devem ser processadas cataliticamente, mas devese levar em consideração que, tanto as condições de processo para a reação inversa, como os catalisadores de escolha não devem ser necessariamente os mesmos da reação de síntese de etanol.

$\mathrm{O}$ exposto acima define, de uma forma geral, a linha de pesquisa do projeto institucional do IPEN/CNEN-SP. No âmbito das células de baixa temperatura de operação, já está em andamento (desde o final de 1998) a instalação da infra-estrutura do projeto "Desenvolvimento de Catalisadores e Eletrocatalisadores para a Oxidação Direta e Indireta de Etanol em Células a Combustível com Membrana Polimérica Condutora de Prótons".

Outro acontecimento recente importante relacionado à esta tecnologia foi a aprovação de um ambicioso projeto de caráter ambiental entre a ONU (Organização das Nações Unidas) e o governo brasileiro, por intermédio do Ministério de Minas e Energia, sob a coordenação de Dra. Marietta Matos e Dr. Demóstenes Barbosa da Silva chamado "Estratégia Ambiental para Energia: Ônibus com Célula a Combustível a Hidrogênio para o Brasil". Este projeto visa, a médio prazo, a utilização de vários ônibus movidos a hidrogênio, com eletrotração a PEMFC no transporte coletivo, na cidade de São Paulo. As fases de avaliação e estruturação já se encontram em andamento. Participam ainda deste projeto a EMTU (Empresa Metropolitana de Transportes Urbanos), a USP-São Carlos e a AAE (Agência para Aplicação de Energia) da Secretaria de Energia do Estado de São Paulo.

É muito importante para o Brasil, que várias instituições se dediquem, de formas variadas à tecnologia de células a combustível, como pesquisa; projeto; combustível; aplicações; etc., para que o país possa, a médio prazo, recuperar o tempo perdido e esteja em condições de nuclear empresas no setor, capazes de competir no mercado futuro de energia. Este mercado será, seguramente, mais exigente, tanto em relação à eficiência de aplicação das fontes de energia, como em relação ao aspecto ambiental.

\section{AGRADECIMENTOS}

Os autores agradecem a Fundação de Amparo a Pesquisa do Estado de São Paulo FAPESP, pelo auxílio concedido à visita do Prof. Dr. H. Wendt ao Brasil.

\section{REFERÊNCIAS}

1. Appleby, A. J.; Foulkes, F. R.; Fuel Cell Handbook; Ed. Van Nostrand Reinhold; New York, EUA, 1989.

2. Appleby, A. J.; Fuel Cells: Trends in Research and Application; Ed. Hemisphere/Springer; Washington, EUA, 1987.

3. Volumes da: Electrochemical Society; Por exemplo: Proc. of the Carbonate Fuel Cells Technology

4. Volumes dos Seminários bienais: Fuel Cell Seminars; Por exemplo: Proc. Fuel Cell Seminar Orlando, Florida, USA, 1996; Courtesy Associates Inc.; Washington DC, EUA, 1996.

5. Volumes da: Electrochimica Acta; Por exemplo: Fuel Cells, 1998, 43.

6. Raistrick et. al.; Diaphagms, "Separators and Ion Exchange Membranes", The Electrochemical Society, Pennington, NJ, 1986, 172.

7. Gottesfeld e colaboradores; J. Appl. Electrochem. 1992, 22

8. Kordesch, K.;. Simader, G.; Fuel Cell and their Application; Ed. VCH; Weinheim, Alemanha, 1996. 
9. Selman, J. F.; Uchida, I.; Wendt, H.; D. A. Shores, D. A. e Fuller, F. F.; The Electrochemical Society; Pennington, N. J., EUA, 1997.

10. Ticianelli, E. A. e Gonzalez, E. R.; Quim. Nova 1989 , 12, 208.

11. Savinell, R. F.; ARPA/URI Quarterly Report 1994, 10.
12. Wang, J. T. e Colaboradores; Electrochim. Acta 1996, 41, 193.

13. Wasmus, S.; Wang, J. T. e Savinell, R. F.; J. Electrochem. Soc. 1995, 142, 3825.

14. Wang, J. T.; Wasmus, S. e Savinell, R. F.; J. Electrochem. Soc. 1995, 142, 4218. 